\title{
Detection of Clostridium difficile and toxin genes in samples of modified atmosphere packaged (MAP) minced and cubed beef meat ${ }^{* * * *}$
}

\author{
Fatma ATASOY, Ali GÜCÜKOĞLU
}

Ondokuz Mayıs University, Faculty of Veterinary Medicine, Department of Food Hygiene and Technology, Samsun, Turkey.

Summary: In this study it is intended to find out the prevalence of Clostridium difficile in modified atmosphere packaged (MAP) minced (n:50) and cubed beef meat samples ( $\mathrm{n}: 50)$; determine the toxin from the isolates and detect the antibiotic susceptibility against metronidazole, vancomycin and clindamycin. C. difficile isolates have been isolated from two (4\%) of 50 minced beef meat samples; one (2\%) of 50 cubed beef meat samples. All three isolates were confirmed by PCR as $C$. difficile by the detection of tpi gene. Three out of 5 C. difficile isolates showed toxigenic character, two of them were carried type B $(t c d B)$ toxin genes, one of them harbored type A $(t c d A)$ toxin gene. When antibiotic resistance profile was phenotypically analyzed, only $C$. difficile type A (tcdA) was found resistant against clindamycin. All isolates were found sensitive to vancomycin and metronidazole. The result of this study demonstrated that $C$. difficile strains detected in samples of modified atmosphere packaged (MAP) beef meat could be a potential problem to public health.

Keywords: Antibiotic resistance, Clostridium difficile, MAP minced-cubed beef meat, mPCR.

\section{Modifiye atmosfer paketli (MAP) sığır kıyma ve kuşbaşı et örneklerinde Clostridium difficile ve toksin genlerinin belirlenmesi}

Özet: Bu çalışmada konvansiyonel yöntem ve multipleks PCR (mPCR) tekniği ile modifiye atmosfer paketli (MAP) sığır kıyma (n:50) ve kuşbaşı (n:50) örneklerinde Clostridium difficile prevalansı, izolatlardaki toksin gen tipinin belirlenmesi ve metronidazol, vankomisin ve klindamisin antibiyotiklerine karşı duyarlılıklarının tespiti amaçlanmıştır. 50 sığır kıyma örneğinin ikisinde (\% 4), 50 sığır kuşbaşı örneğinin birinde (\% 2), C. difficile saptanmıştır. Multipleks PCR ile yapılan analizlerde, konvansiyonel yöntemle belirlenen toplam beş izolat ile tpi geninin tespiti ile $C$. difficile olarak doğrulanmıştır. $C$. difficile izolatlarının toksin gen varlığı değerlendirildiğinde beş izolatın üçü toksijenik karakterde olup ikisinde $C$. difficile tip B $(t d c B)$, birinde ise $C$. difficile tip A (tdcA) toksin geni tespit edilmiştir. Fenotipik antibiyotik direnç profili analizinde klindamisine karşı yalnızca $C$. difficile tip A (tdcA) toksin genini içeren izolat dirençli bulunurken, tüm izolatlar vankomisine ve metronidazole karşı duyarlı bulunmuştur. Çalışma sonucunda modifiye atmosfer paketli (MAP) et örneklerinde tespit edilen $C$. difficile'nin halk sağlı̆̆ için potansiyel bir tehlike olabileceği ortaya konmuştur.

Anahtar sözcükler: Antibiyotik dirençlilik, Clostridium difficile, MAP sığır kıyma ve kuşbaşı, mPCR.

\section{Introduction}

Clostridium difficile is a Gram-positive sporeforming bacterium that has ability to produce two toxins called toxin A (enterotoxin) and toxin B (potent cytotoxin) (23). Spore production renders $C$. difficile highly resistant to environmental stress factors $(7,16,24)$. Infections can lead humans to be asymptomatic carriers or can cause clinical diseases that range from modest diarrhea to life aggressive pseudomembranous colitis. The bacterium also comes out to be a serious cause of enteric disease in a wide range of animal groups (22). It has been suggested that cross contamination of pathogenic $C$. difficile between animals, environments and humans is possible; additionally, it can be isolated from varying food and food producing animals which are identical to strains implicated in human diseases (26). The presence of important food originated $C$. difficile strains has raised concerns about the possibility for food-borne transmission, although the action of food in human $C$. difficile infections (CDI) has not been thoroughly investigated (30). Studies in various countries have determined differences in the prevalence of $C$. difficile in

\footnotetext{
* This article is a part of the master thesis of the first author.

** The abstract of this research was published in the proceedings of the International Conference on Biochemistry and Molecular Biology. 22-23 April-2015. Paris, France.
} 
livestock (1, 10, 11, 20, 31). In particular, C. difficile ribotype 078 is generally found in animal originated food and a progressively described origin of communityrelated $C$. difficile infection (CDI) in humans $(3,12,16$, 28, 29). In 2009, C. difficile ribotype 078 was among the three most frequent ribotypes of $C$. difficile isolated from humans in European countries (2).

The prevalence of $C$. difficile in retail beef samples in Turkey has not been reported previously. Hence there is no accessible data on the potential risk of $C$. difficile infection posed by beef meat products in Turkey. The primary objectives of this study is to determine the prevalence of $C$. difficile in modified atmosphere packaged (MAP) minced and cubed beef meat, to find out the toxin gene ( $t c d A$ and $t c d B)$ using multiplex PCR and to determine antibiotic resistance against metronidazole, vancomycin and clindamycin.

\section{Materials and Methods}

In this study, a total of 100 meat samples including 50 MAP minced and 50 cubed beef collected from retail shops and supermarkets between May to October 2013 in Samsun, Turkey. All samples were transferred to the laboratory in a cooler box with ice $\left(4-8{ }^{\circ} \mathrm{C}\right)$ and analyzed immediately for the isolation of $C$. difficile.

Isolation and identification of $C$. difficile: Isolation and identification of $C$. difficile with classical culture technique performed according to Boer et al. (3). Each MAP meat sample $(5 \mathrm{~g}$ ) was diluted in $C$. difficile broth (20 ml-CD broth) [proteose peptone (Oxoid, LP085), disodium hydrogen phosphate (Sigma, S79075), potassium dihydrogen phosphate (Sigma, P97911), magnesium sulphate (Sigma, M75060), sodium chloride (Sigma, S76532), fructose (Sigma, F01276), sodium taurocholate (Sigma, S863391), laked horse blood (Oxoid, SR0048C), C. difficile selective supplement (Oxoid, SR0173E)]. The inoculated CD broth was incubated under anaerobic cases with gas generating kit (Oxoid, BR38) in a jar and covered with sterile paraffin oil at $37{ }^{\circ} \mathrm{C}$ for 15 days. After 15 days of incubation, $2 \mathrm{ml}$ from the enriched culture was added to $2 \mathrm{ml}$ ethanol (96\%) in a centrifuge tube and homogenized for 50 minutes on a shaker. Afterwards centrifugation $(3800 \times \mathrm{g}$ for $10 \mathrm{~min}$-HettichUniversal-320R, Germany), a loop full substantial from the sediment was streaked onto Clostridium difficile moxolactam norfloxacin agar (CDMN agar) [proteose peptone (Oxoid, LP085)], disodium hydrogen phosphate (Sigma, S79075), potassium dihydrogen phosphate (Sigma, P97911), magnesium sulphate (Sigma, M75060), sodium chloride (Sigma, S76532), fructose (Sigma, F01276), agar bacteriological (Oxoid, LP11), laked horse blood (Oxoid, SR0048C), C. difficile selective supplement (Oxoid, SR0173E)]. The plates were incubated for 24 to $48 \mathrm{~h}$ at $37{ }^{\circ} \mathrm{C}$, under anaerobic situations and up to 5 uncertained colonies (large, irregularly circular, yellowgreen colour under $360 \mathrm{~nm}$ UV light, smooth, grayish and considered akin to a tennis racket with Gram positive staining) were subcultured on Tryptone Soya Agar (Oxoid, CM0131) under similar anaerobic conditions. Probable recognition of uncertain colonies was achieved by checking for agglutination using the $\mathrm{C}$. difficile test kit (Oxoid, DR1107A). Also typical colonies were grown in $\mathrm{CD}$ broth at $37{ }^{\circ} \mathrm{C}$ for $24-48$ hours for subcultures. Bacterial suspensions were practiced to form template DNA for PCR.

DNA extraction: The isolates were grown on $\mathrm{CD}$ broth (overnight at $37^{\circ} \mathrm{C}$ ). $500 \mu \mathrm{l}$ cell suspensions were suspended in $0.5 \mathrm{ml}$ distilled water and after heating for $10 \mathrm{~min}$ at $95^{\circ} \mathrm{C}$ (Memert, Germany), the suspension was centrifuged ( $5 \mathrm{~min}, 10,000 \mathrm{~g}$ at $+4{ }^{\circ} \mathrm{C}$, Hettich Universal320R, Germany) and $2.5 \mu \mathrm{l}$ of the supernatant was practiced as template in the MPCR examinations.

Determination of tpi, tcdA and tcdB genes from $C$. difficile isolates by multiplex PCR: In total, 5 isolates of C. difficile were tested for $t p i, t c d A$ and $t c d B$ genes by mPCR. According to Lemee et al. (15), specific primers were used for the recognition of the genes. All the primer couples used in this study are listed in Table 1.

Table 1. Characteristics primers used for detection of $t p i, t c d A$ and $t c d B$ genes.

Tablo 1. tpi, $t c d A$ ve $t c d B$ genlerine ait primer dizilimleri.

\begin{tabular}{lccc}
\hline \multicolumn{1}{c}{ Primer } & Sequence $\left(5^{\prime}-3^{\prime}\right)$ & $\begin{array}{c}\text { Product size } \\
(\mathrm{bp})\end{array}$ & Reference \\
\hline$t p i \mathrm{~F}$ & AAAGAAGCTACTAAGGGTACAAA & & Lemee et al. (15) \\
$t p i \mathrm{R}$ & CATAATATTGGGTCTATTCCTAC & 230 & Lemee et al. (15) \\
$t c d A \mathrm{~F}$ & AGATTCCTATATTTACATGACAATAT & 369 & Lemee et al. (15) \\
$t c d A \mathrm{R}$ & GTATCAGGCATAAAGTAATATACTTT & & \\
$t c d B \mathrm{~F}$ & GGAAAAGAGAATGGTTTTATTAA \\
$t c d B \mathrm{R}$ & ATCTTTAGTTATAACTTTGACATCTTT & 160 & \\
\hline
\end{tabular}




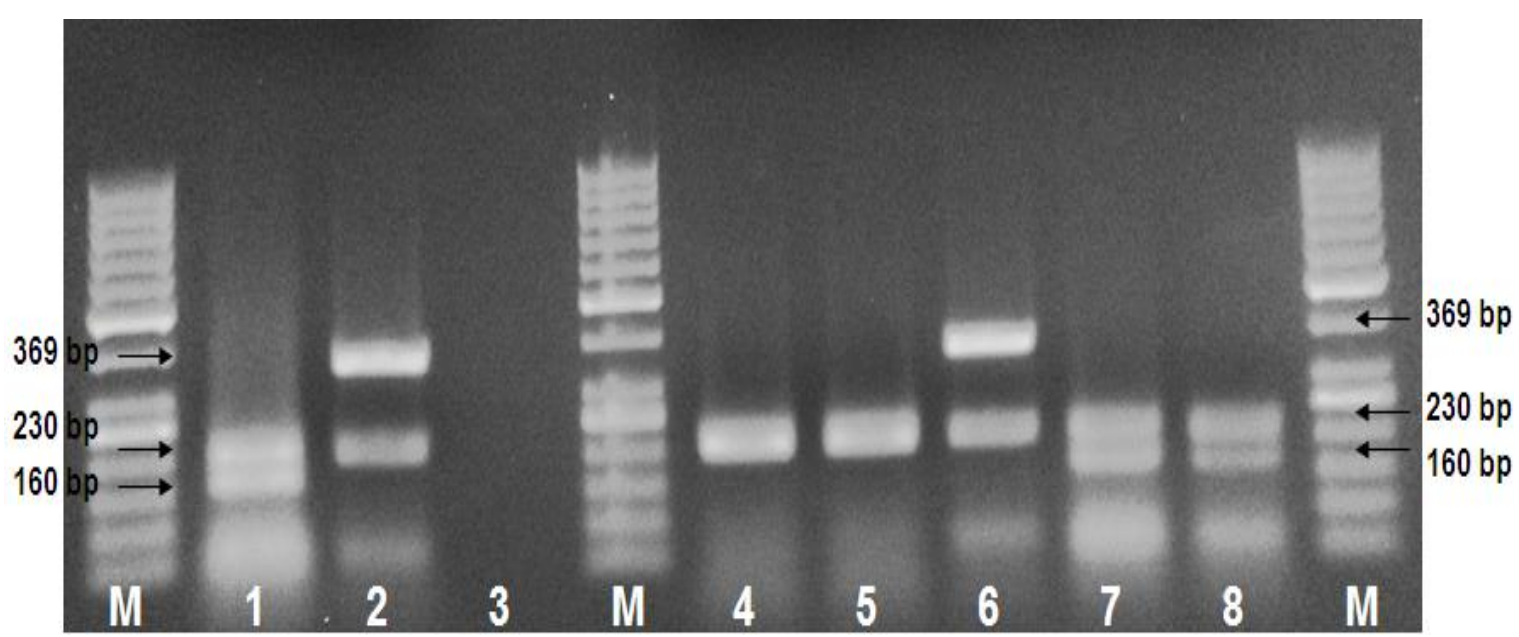

Figure 1. Electrophorese image of isolates by multiplex PCR. [M: 100 bp DNA marker, lane 1: Positive control for tpi and $t c d B$ genes (C. difficile ATCC 9689), lane 2: Positive control for tpi and $t c d A$ genes (C. difficile ATCC 43593), lane 3: Negative control, lane 4: MAP cubed beef meat samples isolates, $t p i$, lane 5: MAP minced beef meat samples isolates, $t p i$, lane 6: MAP minced beef meat samples isolates, $t p i$ and $t c d A$, lane 7: MAP minced beef meat samples isolates $t p i$ and $t c d B$, lane 8: MAP minced beef meat samples isolates $t p i$ and $t c d B]$.

Şekil 1. Multipleks PCR elektroforez görüntüsü [M: 50 bp DNA marker, 1: tpi ve $t c d B$ pozitif kontrol (C. difficile ATCC 9689), 2: tpi ve $t c d A$ pozitif kontrol (C. difficile ATCC 43593), 3: negatif kontrol, 4: tpi pozitif MAP sığır kuşbaşı orijinli izolat, 5: tpi pozitif MAP sığır kıyma orijinli izolat, 6: tpi ve $t c d A$ pozitif MAP sığır kıyma orijinli izolat, 7: tpi ve $t c d B$ pozitif MAP sığır kıyma orijinli izolat, 8: $t p i$ ve $t c d B$ pozitif MAP sığır kıyma orijinli izolat].

mPCR emplification and gel electrophoresis: In attempt to amplify the relevant genes, PCR mixture was prepared as follows: a final volume of $25 \mu \mathrm{l}$ containing $200 \mu \mathrm{M}$ of each dNTP (Sigma), $2.5 \mathrm{mM} \mathrm{MgCl}_{2}$ (Sigma), $1 \mu \mathrm{M}$ (each) of $t p i$, $t c d A$ and $t c d B$ primers, $0.5 \mathrm{U}$ Taq polymerase (Sigma) in $10 \mathrm{mM}$ Tris- $\mathrm{HCl}$ (pH 8.3), $50 \mathrm{mM}$ $\mathrm{KCl}, 5 \mu \mathrm{l} 10 \mathrm{X}$ reaction buffer (Sigma) and $2.5 \mu$ template DNA. The volume of this mixture was adjusted to $25 \mathrm{ml}$ with sterile water. The amplification of the corresponding genes: $t p i, t c d A$ and $t c d B$ was performed in a Thermal Cycler (Bio-Rad MH mini Gradient CA-USA) with a temperature program consisting of the initial denaturation at $94{ }^{\circ} \mathrm{C}$ for 3 minutes and 40 cycles followed by denaturation at $94{ }^{\circ} \mathrm{C}$ for 60 seconds, annealing of the primers at $55^{\circ} \mathrm{C}$ for 2 minute, extention of the primers at $72{ }^{\circ} \mathrm{C}$ for 0.5 minute and final extension at $72{ }^{\circ} \mathrm{C}$ for 7 minutes Lemee et al. (15). The acquired amplicons were run on 2\% agarose gel (Sigma A9539) at $90 \mathrm{~V}$ for 90 minutes of electrophoresis (Biarad-Powerpac. basic). 100 bp DNA ladder was used as DNA size marker in the process of electrophoresis. At the end of the electrophoresis bands with the following molecular weight were considered to be positive for the matching genes: $369 \mathrm{bp}$ for $t c d A, 230 \mathrm{bp}$ for $t p i, 160 \mathrm{bp}$ for $t c d B$ (Figure 1).

Antimicrobial susceptibility: Antimicrobial susceptibility testing was worked using the disc diffusion process. Three antibiotic discs were chosen as follows: metronidazole (5 $\mu \mathrm{g})$, (Oxoid, CT067B), vancomycin (30 $\mu \mathrm{g}),($ Oxoid, CT058B) and clindamycin $(2 \mu \mathrm{g})$, (Oxoid, CT064B). Fresh bacterial colonies were grown under anaerobic conditions with gas generating kit (Oxoid, BR38) in a jar and coated with sterile paraffin oil at $37^{\circ} \mathrm{C}$ for $24 \mathrm{~h}$ in Brucella broth (Sigma, B3051). After incubation the turbidity level was fixed to $0.5 \mathrm{McFarland}$ with a compact benchtop densitometer (Biosan, DEN-1, Latvia), and then $1 \mathrm{ml}$ of suspension was inoculated on Brucella agar (Oxoid, CM0169-added 5\% with laked horse blood- Oxoid, SR0048C) plates and spread similar. The plates were incubated at $37^{\circ} \mathrm{C}$ for $18-24 \mathrm{~h}$. The inhibition zones were sized and scored as sensitive, intermediate susceptibility as stated by the recommendations of the Clinical and Laboratory Standards Institute (5).

\section{Results}

This is the first report of $C$. difficile isolated from modified atmosphere packaged (MAP) minced (n:50) and cubed beef (n:50) samples in Turkey. According to our analysis results, $C$. difficile strains have been identified in 2 of $50(4 \%)$ minced beef meat samples and in 1 of 50 (2\%) cubed beef meat samples. Additionally, MAP meat samples contaminated with $C$. difficile detected in a total of 3 positive isolates were identified from 5 samples. Toxigenic character was observed in $3(60 \%)$ out of 5 isolates. MAP ground meat sample of the positive isolates 3 in $4(75 \%)$ were identified as the toxigenic character and $1(25 \%)$ of them were found to contain the gene of $t c d A$ and $2(50 \%)$ were found to contain the gene of $t c d B$. Toxigenic structure could not be determined in one positive isolate from the MAP minced meat sample (Table 2). 
Table 2. Prevalence of $t p i, t c d A$ and $t c d B$ genes in $C$. difficile isolates from MAP minced and cubed beef meat samples. Tablo 2. tpi, $t c d A$ ve $t c d B$ genlerine sahip $C$. difficile izolatlarının MAP kuşbaşı ve kıyma örneklerindeki dağılımı.

\begin{tabular}{|c|c|c|c|c|c|}
\hline \multirow[t]{2}{*}{ Samples } & \multirow{2}{*}{$\begin{array}{c}\text { Number of } \\
\text { C. difficile } \\
\text { positive samples } \\
(\%)\end{array}$} & \multirow{2}{*}{$\begin{array}{l}\text { Number of of } \\
C . \text { difficile } \\
\text { positive isolates } \\
\text { (tpi gene) }\end{array}$} & \multirow{2}{*}{$\begin{array}{c}\text { Number of } \\
\text { toxigenic } C \text {. difficile } \\
\text { isolates }\end{array}$} & \multicolumn{2}{|c|}{ Toxigenic gene } \\
\hline & & & & $t c d A$ & $t c d B$ \\
\hline $\begin{array}{l}\text { MAP minced beef meat } \\
n=50\end{array}$ & $2(4 \%)$ & 4 & 3 & 1 & 2 \\
\hline $\begin{array}{l}\text { MAP cubed beef meat } \\
\qquad \mathrm{n}=50\end{array}$ & $1(2 \%)$ & 1 & - & - & - \\
\hline $\begin{array}{c}\text { Total } \\
\mathrm{n}=100\end{array}$ & $3(3 \%)$ & 5 & 3 & 1 & 2 \\
\hline
\end{tabular}

Table 3. Molecular characteristics and antibiotic resistance profiles of $C$. difficile isolates from MAP minced and cubed beef meat samples.

Tablo 3. MAP kuşbaşı ve kıyma örneklerindeki C. difficile izolatlarının moleküler karakterizasyonu ve antibiyotik dirençlilik profilleri.

\begin{tabular}{|c|c|c|c|c|c|c|c|c|c|c|c|c|}
\hline \multirow[t]{3}{*}{ Orgin of Isolates/Code } & \multicolumn{3}{|c|}{ Molecular Characterization } & \multicolumn{9}{|c|}{ Results of Phenotipic Disc Diffusion Test } \\
\hline & \multirow{2}{*}{$\begin{array}{l}\text { tpi } \\
\text { gene }\end{array}$} & \multirow{2}{*}{$\begin{array}{l}t c d A \\
\text { gene }\end{array}$} & \multirow{2}{*}{$\begin{array}{l}t c d B \\
\text { gene }\end{array}$} & \multicolumn{3}{|c|}{$\begin{array}{l}\text { Metronidazol } \\
\quad(5 \mu \mathrm{g})\end{array}$} & \multicolumn{3}{|c|}{$\begin{array}{l}\text { Vancomycin } \\
(30 \mu \mathrm{g})\end{array}$} & \multicolumn{3}{|c|}{$\begin{array}{l}\text { Clindamycin } \\
(2 \mu \mathrm{g})\end{array}$} \\
\hline & & & & $\mathrm{R}$ & I & $\mathrm{S}$ & $\mathrm{R}$ & I & $\mathrm{S}$ & $\mathrm{R}$ & I & $\mathrm{S}$ \\
\hline $\begin{array}{l}\text { MAP minced beef meat } \\
\text { (Code: } 33-1)\end{array}$ & + & + & - & - & - & + & - & - & + & + & - & - \\
\hline $\begin{array}{l}\text { MAP minced beef meat } \\
\text { (Code:33-2) }\end{array}$ & + & - & - & - & - & + & - & - & + & - & - & + \\
\hline $\begin{array}{l}\text { MAP minced beef meat } \\
\text { (Code: } 70-2)\end{array}$ & + & - & + & - & - & + & - & - & + & - & - & + \\
\hline $\begin{array}{l}\text { MAP minced beef meat } \\
\text { (Code: } 70-2)\end{array}$ & + & - & + & - & - & + & - & - & + & - & - & + \\
\hline $\begin{array}{l}\text { MAP cubed beef meat } \\
\text { (Code: } 80-1)\end{array}$ & + & - & - & - & - & + & - & - & + & - & - & + \\
\hline
\end{tabular}

R: Resistant, I: Intermediate, S:Sensitive

With the multiplex PCR molecular evaluations, a total of five isolates known by conventional methods were confirmed by PCR and verified as $C$. difficile tpi gene. When properties isolated from $C$. difficile were evaluated, 3 out of 5 showed toxigenic character, two of them were identified as $C$. difficile type B $(t c d B)$ toxin genes, one of them as $C$. difficile type A (tcdA) toxin gene (Figure 1).

\section{Discussion and Conclusion}

The results were in agreement with those (2\%) reported by Jöbstl et al. (13) who used PCR to assess 200 pork and beef samples from Austrian city of Graz. The results in our study are in general, consistent with the results of Von Abercron et al. (27) who conducted a survey on the prevalence of $C$. difficile in meat samples. They detected $C$. difficile in $2.4 \%$ samples in Sweden. Likewise akin to incidence levels were realized by other researchers, including Bouttier et al. (4) who analyzed 105 meat samples in France and encountered the incidence of C. difficile in $1.9 \%(2 / 105)$ of the samples. Esfandiari et al. (8) determined that $2.1 \%$ of 81 meat samples were contaminated by $C$. difficile in Iran. 133 meat samples obtained in Belgium were tested by Rodriguez et al. (21) who declared that $2.3 \%$ of the samples were contaminated with $C$. difficile.

Comparison to past studies which reported great contamination percentage of the meat samples analyzed for the $C$. difficile, overall contamination rate in our study was relatively low (3\%). Rodriguez et al. (20) microbiologically analyzed meat samples in Canada and found high prevalence of $C$. difficile (20\%) in samples of meat. Songer (25) determined that $42 \%$ of 88 meat samples were contaminated by $C$. difficile in USA. Weese et al. (29) reported that 14 of 115 (12\%) meat samples obtained in Canada were contaminated with $C$. difficile. The high prevalence ratios stated in the studies pictured above might be caused by weak sanitation and disinfection of both equipment and poor conditions of hygiene and/or owing to geographical reasons.

Rodriguez-Palacios and LeJeune (19) reported 11 $(91.6 \%)$ of 12 positive isolates that were detected in retail meat products sold in Canada had toxigenic character. In the study performed by the same researchers in 2009, 10 (76.9\%) of 13 positive isolates were identified to have toxigenic structure. 
Jöbstl et al. (13) detected toxigenic structure in 1 $(50 \%)$ of 2 positive isolates obtained from pork-beef meat mixture there of samples obtained from the butchers did not have both the $t c d A$ and $t c d B$ gene; MAP positive isolate samples obtained from the supermarket was reported to have both gene sequences.

Von Abercron et al. (27) reported in a study conducted in Sweden that they have detected 2 positive isolates from samples obtained from ground beef sold in retail which also showed toxigenic structure and carried both $(100 \%) t c d A$ and $t c d B$ genes.

In our study antibiotic resistance screening in meat samples against strains of positive isolates of $C$. difficile were tested with disc diffusion method. Studies showed resistance against clindamycin (20\%) and 100\% sensitivity against vancomycin and metronidazole (Table 3).

Similar to our study performed with meat samples Bouttier et al. (4) reported sensitivity against vancomycin and metronidazole in raw beef meat. However, in addition our study showed $20 \%$ resistance against clindamycin.

Analogous to our results, a study carried out in Texas by Harvey et al. (9) reported resistance against clindamycin; and $100 \%$ sensitivity against vancomycin and metronidazole in positive isolates obtained from meat products.

Studies performed in Belgium by Rodriguez et al. (19) detected $50 \%$ antibiotic sensitivity against positive isolates obtained from beef and pork meat, while studies showed mild resistance against clindamycin; all isolates were reported to be susceptible against metronidazole and vancomycin.

Antibiotic susceptibility testing performed on isolates of $C$. difficile identified in meat samples obtained from different species; Rahimi et al. (17) reported high resistance against clindamycin and all isolates were susceptible against metronidazole and vancomycin.

Kauassi et al. (14) in their study examined some antibiotics sensitivity on positive isolates identified from cooked meat, as results of their study: $100 \%$ susceptibility against metronidazole, vancomycin and $12.25 \%$ resistance against clindamycin was determined.

This study points out that the probable effect of food, including meat and meat products, as an origin of transmittal of $C$. difficile to people. Slaughterhouses may be seriously infected with foodborne organisms. But we do not manage to allege that farm animals are the only source of $C$. difficile meat infection. The origin can contain fecal or indirect contamination of meat at slaughterhouse but also contamination throughout preparing in meat plants. This study is the first report on the prevalence of $C$. difficile in retail beef meat samples in Turkey. Our findings provide some baseline knowledge regarding the prevalence of these important $C$. difficile isolated from modified atmosphere packaged meat products that could be used in future studies. In order to achieve good manufacturing practice and food safety from farm to fork process, further work should focus on transmission, monetarization and control of zoonotic pathogens in animal food products.

\section{Acknowledgement}

This work was supported by Ondokuz Mayis University (Project no: PYO.VET.1904.12.003).

\section{References}

1. Baker AA, Davis E, Rehberger T, et al. (2010): Prevalence and diversity of toxigenic Clostridium perfringens and Clostridium difficile among swine herds in the midwest. Appl Environ Microbiol, 76, 2961-2967.

2. Bauer MP, Notermans DW, Van Benthem BH (2011): Clostridium difficile infection in Europe: A hospital-based survey. Lancet, 377, 63-73.

3. Boer E, Zwartkruis-Nahuis A, Heuvelink AE, et al. (2011): Prevalence of Clostridium difficile in retailed meat in The Netherlands. Int J Food Microbiol, 144, 561-564.

4. Bouttier S, Barc M, Felix B, et al. (2005): Clostridium difficile in ground meat, France. Emerg Infect Dis, 16, 733.

5. Clinical and Laboratory Standards Institute (CLSI) (2012): Methods for Antimicrobial Susceptibility Testing of Anaerobic Bacteria; Approved Standard - Eighth Edition, M11A8E W. Hecht, et al 2012: Clinical and Laboratory Standards Institute.

6. Curry SR, Marsh JW, Schlackman JL, et al. (2005): Prevalence of Clostridium difficile in uncooked ground meat products from Pittsburgh, Pennsylvania. Appl Envir Microbiol, 78, 4183.

7. Deneve C, Janoir C, Poilane I, et al. (2009): New trends in Clostridium difficile virulence and pathogenesis. Int $\mathrm{J}$ Antimicrob Agent, 33 Suppl 1, 24-28.

8. Esfandiari Z, Jalali M, Ezzatpanah H, et al. (2014): Prevalence and characterization of Clostridium difficile in beef and mutton meats of Isfahan region, Iran. Jundishapur J Microbiol, 7, 16771.

9. Harvey RB, Norman KN, Andrews K, et al. (2011): Clostridium difficile in retail meat and processing plants in Texas. J Vet Diag Invest, 23, 807-811.

10. Hoffer E, Haechler H, Frei R, et al. (2010): Low occurrence of Clostridium difficile in fecal samples of healthy calves and pPigs at slaughter and in minced meat in Switzerland. J Food Prot, 73, 973-975.

11. Houser BA, Soehnlen MK, Wolfgang DR, et al. (2012): Prevalence of Clostridium difficile toxin genes in the feces of veal calves and incidence of ground veal contamination. Foodborne Pathog Dis, 9, 32-36.

12. Janezic S, Ocepe, M, Zidaric M, et al. (2012): Clostridium difficile genotypes other than ribotype 078 that are prevalent among human, animal and environmental isolates. BMC Microbiol, 12, 48.

13. Jöbstl M, Heuberger S, Indra A, et al. (2008): Clostridium difficile in raw products of animal origin. Int $\mathrm{J}$ Food Microbiol, 138, 172-175. 
14. Kouassi KA, Dadie AT, N'Guessan KF, et al. (2014): Clostridium perfringens and Clostridium difficile in cooked beef sold in $C^{\wedge}$ ote d'Ivoire and their antimicrobial susceptibility. Anaerob, 28, 90-94.

15. Lemee L, Dhalluin A, Testelin S, et al. (2004): Multiplex PCR targeting tpi (Triose Phosphate Isomerase), tcdA (Toxin $A)$, and tcdB (Toxin B) genes for toxigenic culture of Clostridium difficile. J Clin Microbiol, 42, 5710-5714.

16. McFarland LV, Elmer GW, Surawicz CM (2002): Breaking the cycle: Treatment strategies for 163 cases of recurrent Clostridium difficile disease. Am J Gastroenterol, 97, 1769-75.

17. Rahimi E, Jalali M, Weese JS (2014): Prevalence of Clostridium difficile in raw beef, cow, sheep, goat, camel and buffalo meat in Iran. BMC Public Health, 14, 119.

18. Rodriguez-Palacios A, Reid-Smith RJ, Staempfli HR, et al. (2009): Possible seasonality of Clostridium difficile in retail meat, Canada. Emerg Infect Dis, 15, 802-805.

19. Rodriguez-Palacios A, LeJeune JT (2011): Moist-heat resistance, spore aging, and super dormancy in Clostridium difficile. Appl Environ Microbiol, 77, 3085-3091.

20. Rodriguez C, Avesani V, Van Broeck J, et al. (2013): Presence of Clostridium difficile in pigs and cattle intestinal contents and carcass contamination at the slaughterhouse in Belgium. Int J Food Microbiol, 166, 256-262.

21. Rodriguez C, Taminiau B, Avesani V, et al. (2014): Multilocus sequence typing analysis and antibiotic resistance of Clostridium difficile strains isolated from retail meat and humans in Belgium. Food Microbiol, 42, 166-171.

22. Rupnik M (2007): Is Clostridium difficile-associated infection a potentially zoonotic and foodborne disease? Clin Microbiol Infect, 13, 457-459.

23. Rupnik M, Wilcox MH, Gerding DN (2009): Clostridium difficile infection: New developments in epidemiology and pathogenesis. Nat Rev Microbiol, 7, 526-536.

24. Samore MH, Venkataraman L, DeGirolami PC, et al. (1996): Clinical and molecular epidemiology of sporadic and clustered cases of nosocomial Clostridium difficile diarrhea. Am J Med, 100, 32-40.
25. Songer JG (2004): The emergence of Clostridium difficile as a pathogen of food animals, Anim Health Res Rev, 5, 321-326.

26. Songer JG, Trinh HT, Killgore GE, et al. (2009): Clostridium difficile in retail meat products, USA 2007. Emerg Infect Dis, 15, 819-821.

27. Von Abercron, SM, Karlsson F, Wigh GT, et al. (2009): Low occurrence of Clostridium difficile in retail ground meat in Sweden. J Food Protect, 72, 1732-1734.

28. Warny M, Pepin J, Fang A, Killgore G, et al. (2005): Toxin production by an emerging strain of Clostridium difficile associated with outbreaks of severe disease in North America and Europe. Lancet, 366, 1079-1084.

29. Weese JS, Avery BP, Rousseau J, et al. (2009): Detection and enumeration of Clostridium difficiles spores in retail beef and pork. Appl Environ Microbiol. 75, 5009-5011.

30. Wilcox MH, Mooney L, Bendall R (2008): A case-control study of community-associated Clostridium difficile infection. J Antimicrob Chemother, 62, 388-96.

31. Zidaric V, Zemljic M, Janezic S, et al. (2008): High diversity of Clostridium difficile genotypes isolated from a single poultry farm producing replacement laying hens. Anaerob, 14, 325-327.

Geliş tarihi: 02.02.2016 / Kabul tarihi: 20.09.2016
Address for correspondence:
Ali Gücükoğlu
Ondokuz Mayls University,
Faculty of Veterinary Medicine,
Department of Food Hygiene and Technology,
Kurupelit, Samsun,Turkey.
Telephone: $+903623121919-2812$
Fax: +903624576622
e-mail:aligucuk77@hotmail.com 